\title{
Hyoscyamus reticulatus L. Tohum Ekstraktının Antimikrobiyal ve Apoptotik Etkinliğinin Araștırılması
}

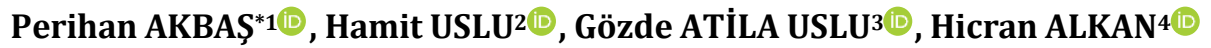 \\ ${ }^{1}$ Kafkas Üniversitesi, Atatürk Sağlık Hizmetleri Meslek Yüksekokulu, Tıbbi Teknik Hizmetler Bölümü, 36100, \\ Kars, Türkiye \\ ${ }^{2}$ Kafkas Üniversitesi, Atatürk Sağlık Hizmetleri Meslek Yüksekokulu, Sağlık Bakım Hizmetleri Bölümü, 36100, \\ Kars, Türkiye \\ ${ }^{3}$ Kafkas Üniversitesi, Veteriner Fakültesi, Veteriner Hekimliği Temel Bilimleri Bölümü, 36100, Kars, Türkiye \\ ${ }^{4}$ Kafkas Üniversitesi, Sosyal Bilimler Meslek Yüksekokulu, Çocuk Gelişimi Bölümü, 36100, Kars, Türkiye
}

(Alınış / Received: 08.10.2019, Kabul / Accepted: 29.05.2020, Online Yayınlanma / Published Online: 20.08.2020)

\author{
Anahtar Kelimeler \\ Antimikrobiyal, \\ Bcl-2, \\ Hyoscyamus reticulatus \\ tohum ekstraktı, \\ TP53
}

\begin{abstract}
Özet: Hyoscyamus reticulatus Solanacea ailesindendir ve ülkemizde altı türü bulunmaktadır. Hyoscyamus türleri özellikle halk arasında yaygın olarak kullanılan skopolamin ve hiyosiyamin gibi tropan alkaloitleri kaynağıdır. H. reticulatus tohumundan soxhlet yöntemi ile elde edilen etil alkol ekstresinin bazı Gram (-) ve Gram (+) bakteri ve mayalara karşı antimikrobiyal aktivitesinin tespit edilmesi ve $H$. reticulatus tohumunun plazma ve beyin numunelerinde TP53 ve Bcl-2 seviyeleri ölçülerek apoptotik etkisinin belirlenmesi amaçlanmıştır. Çalışmada 40 adet Wistar albino cinsi diși sıçan her grupta 10 adet olacak şekilde 4 gruba ayrıldı; Kontrol (K), 125, 250, $500 \mathrm{mg} / \mathrm{kg} \mathrm{H}$. reticulatus ekstrakt gruplarl. H. reticulatus tohumu ekstraktının Bacillus subtilis, Escherichia coli, Klebsiella pneumoniae, Pasteurella multicoda, Pseudomonas aeruginosa, Salmonella enteridis, Staphylococcus aureus, Yersinia enterocolitica bakterileri ve Candida albicans mayasına karşı antimikrobiyal etkinliğinin bulunmadığı tespit edilmiştir. HR250 ve HR500 gruplarının plazma örneklerinde TP53 seviyelerinin K grubuna göre önemli düzeyde arttığı tespit edildi (sırasıyla p<0,01, p<0,001). Ekstrakt uygulanan tüm gruplarla K grubu karşılaştırıldığında; ekstrakt uygulanan gruplarda plazma Bcl-2 seviyelerinin önemli düzeyde azaldığı belirlendi $(\mathrm{p}<0,001)$. Sonuç olarak; $H$. reticulatus tohum ektraktının antimikrobiyal etkisi olmadığı ve in vivo olarak farklı dozlarda uygulanan ekstraktın beyin dokusunda olmasa da diğer organ ve/veya organlarda apoptozisi uyarabileceğini düşünmekteyiz.
\end{abstract}

\section{Investigation of the Antimicrobial and Apoptotic Efficacy of Hyoscyamus retıculatus $\mathrm{L}$. Seed Extract}

Keywords

Antimicrobial,

Bcl-2,

Hyoscyamus reticulatus seed extract,

TP53

\begin{abstract}
Hyoscyamus reticulatus is from Solanacea famil and has six species in our country. Hyoscyamus species are the source of tropan alkaloids, such as scopolamine and hyoctiamine, which are commonly used in public. The aim of this study was to determine the antimicrobial activity of ethyl alcohol extract obtained from $H$. reticulatus seed by soxhlet method against some Gram (+) and Gram (-) bacteria and yeasts and to determine apoptotic effect of $H$. reticulatus seed by measuring TP53 and Bcl-2 levels in plasma and brain samples. 40 Wistar albino female rats were divided into 4 groups in each group with 10 of them; Control (C), $125,250,500 \mathrm{mg} / \mathrm{kg} \mathrm{H}$. reticulatus extract groups. It was found that H. reticulatus seed extract have no antimicrobial activity against Bacillus subtilis, Escherichia coli, Klebsiella pneumoniae, Pasteurella multicoda, Pseudomonas aeruginosa, Salmonella enteridis, Staphylococcus aureus, Yersinia enterocolitica bacteria and Candida albicans yeast. Plasma samples of HR250 and HR500 groups showed significant increase in TP53 levels compared to group C ( $p<0.01, p<0.001$, respectively). Compared to all extract applied groups and group C; Plasma Bcl-2 levels significantly decreased in extract groups $(\mathrm{p}<0.001)$. As a result; we suggest that $H$. reticulatus seed extract does not have an antimicrobial effect and extracts applied in different doses in vivo may stimulate apoptosis in other organ and / or organs, although not in brain tissue.
\end{abstract}




\section{Giriş}

Hyoscyamus cinsi Solanacea ailesindendir ve ülkemizde Dağdağan, Gavur haşhașı, Banotu, Bengildek, Deli bat bat, Berç, Benk, gibi isimlerle tanınır. Hyoscyamus cinsinin 6 türü mevcuttur $(H$. albus L., H. aureus L., H. leptocalyx Stapf., H. niger L., $H$ pusillus L. ve H. reticulatus L.). H. reticulatus bitkisinin tadı acı olup kötü kokar, tüylü yaprakları vardır ve kenarları derin dişli mor çiçeklere sahiptir [1].

Hyoscyamus reticulatus L. Güneybatı Asya, Mısır, İran ve Türkiye'deki en önemli şifalı bitkilerden biridir [2]. Hyoscyamus türleri özellikle halk arasında yaygın olarak kullanılan skopolamin ve hiyosiyamin gibi tropan alkaloitleri kaynağıdır, Hiyosiyamin ve skopolaminin karmaşık kimyasal formülasyonu nedeniyle, sentetik üretimi çok pahalıdır ve bu yüzden Solanaceae bitkilerinden elde edilir [3]. Tropane alkaloidleri, Solanaceae'nin sekonder metabolitlerinin ayırt edici gruplarından birini oluşturur ve bunları içeren birçok bitki, tıbbi, halüsinojenik ve zehirli özellikleri için uzun süredir kullanılmaktadır [4].

İran'da yapılan bir araștırmada Hyoscyamus reticulatus tohumlarının diğer bitki kısımlarından daha yüksek miktarlarda hiyosiyamin içerdiği tespit edilmiştir [5]. Hyoscyamus reticulatus atropin, hyosiyamin, skopolamin gibi tropan alkaloidleri bulundurmaktadır ve bu alkoloidlerin antikolinerjik etkisi vardır. Ayrıca flavonoidler, fenolikler, gliseridler, glikozitler, kumarinolignanlar, lignanlar, saponinler, ve vitanolidler gibi alkaloid olmayan sekonder metabolitler de içerir. İçerdikleri bu alkoloidlerin analjezik, antikolinerjik, antispazmodik, midriyatik, ve sedatif özelliklerinden dolayı yaygın olarak kullanıldığı ileri sürülmektedir [4].

Son yıllarda sağlığı destekleyici ve bütünleştirici alternatif bitkisel ürünler ve bunlardan elde edilen etken maddelerine karşı insanların ilgileri gün geçtikçe artmaktadır. Bu ilgi hızlı artmasına rağmen, alternatif/geleneksel tıbbın etkinliği, toksisitesi ve mekanizmaları hakkında sınırlı sayıda çalışma vardır. İnsanlarda zaman zaman bitkilerle zehirlenme vakaları görülmektedir. Kırsal kesimde insanlar bazen taze sebze bulma açısından zorluk çektiklerinden çoğu zaman doğadan topladıkları bitkileri yerler.

Banotunun kök ve yapraklarının tadı salatalığa benzemektedir ve bu çocukları cezbeder. Van ve Erzincan'da banotunun taze sürgünlerini marula benzettiği için yiyen iki kişinin zehirlenmesi buna bir örnektir. Ayrıca Doğu Anadolu bölgesinde banotu zehirlenmelerine sık rastlanmaktadır [6, 7]. Başka bir türü olan Hyoscyamus niger'in taze sürgünlerinin, kök ve tohumlarının yenilmesi sonucu halisülasyon görme, bulanık görme, kalp ritminde artış gibi belirtiler görülmekte olup ölümle de sonuçlanabildiği bildirilmektedir [5, 8-10]. Yine aynı şeklide, 71 yaşında bronşiyal astım hastası bir kişi, banotu yapraklarının astıma iyi geldiğini duyduğundan banotu yaprağı çayı içmiş; iki saat sonra ağız kuruluğu, çarpıntı, görme ve konuşma bozukluğu gibi belirtiler ortaya çıktığından hastaneye başvurmuştur [11]. Hyoscyamus bitkileri hiposiyamin (atropin) ve skopolamin için doğal bir kaynaktır. Her iki alkaloid de parasempatik sinir sistemi üzerindeki baskılayıcı aktiviteleri nedeniyle tıbbi öneme sahiptir [12].

Ayrıca Anadolu köylerinde bazı köy gençleri tarafından $H$. niger ve $H$. reticulatus tohum ve yapraklarının halüsinojik etkileri nedeniyle kullanıldığg; bu nedenle özellikle tohumlarının, zehirlenmelere neden olduğunu bildirilmiştir [13, 14]. Zehirlenmeler çoğu doku ve organda apoptozu tetiklemekte olup, apoptozis intrinsik mekanizmalarında karşımıza Bcl-2 ve TP53 parametreleri çıkmaktadır. Bcl-2 ailesinin proapoptotik (Bax, Bak, Bid, BclXs, Bim, Puma, Noxa) ve antiapoptotik (Bcl-XL, Bcl-w, Bcl-2, BFL-1/A1, Mcl1) üyelerden oluştuğu belirtilmektedir $[15,16]$. Proapoptotik üyelerin sitokrom-c ve apoptoz indükleyici faktör salınımını arttırarak apoptozu indüklediği, antiapoptotik üyelerin ise özellikle kalsiyum iyon transportunu düzenlediği ve sitokromc ile apoptoz indükleyici faktör salınımını inhibe ederek apoptozu engellediği ifade edilmektedir [17, 18]. $P 53$ 'ün ya da diğer adiyla tümör protein 53'ün (TP53) ise transkripsiyonel bir faktör olduğu hücresel stres ve DNA'nın tamir edilemeyecek kadar zarar gördüğü durumlarda apoptozu uyardığı ileri sürülmektedir [19].

Günümüzde hem zehirlenmelere sebep olan hem de tedavi amacıyla kullanılan bu bitkinin yaprak ekstrelerinin antioksidan ve antimikrobiyal etkileri incelenmiştir, fakat etken maddelerinin daha yoğun olmasının beklendiği tohumların antimikrobiyal ve in vivo çalışmaları yeteri kadar mevcut değildir. $\mathrm{Bu}$ çalışma ile ülkemizde bol oranda yetișen ve toksik etkileri de olduğu belirtilen $H$. reticulatus tohumundan soxhlet yöntemi ile elde edilen etil alkol ekstresinin mikroorganizmalar üzerinde de bir etkisi olup olmadığını anlamak amacı ile; bazı Gram (+) ve Gram (-) bakteri ve mayalara karşı antimikrobiyal aktivitesinin tespit edilmesi ve $H$. reticulatus bitkisinin sinir sistemi üzerindeki etkisini gözlemleyebilmek için plazma ve beyin numunelerinde TP53 ve Bcl-2 seviyeleri ölçülerek apoptotik etkisinin belirlenmesi amaçlanmıştır.

\section{Materyal ve Metot}

\subsection{Materyal ve metot alt başlığı}

Deneylerde kullanılan $H$. reticulatus tohumları Kars İlinden temin edilmiş olup, tohumlar gölgede kurutulduktan sonra ögütülerek analizde kullanılmak için ince toz haline getirilmiştir. 25 gram tohum 500 
$\mathrm{mL}$ etanolde 2 saat boyunca Soxhlet cihazında ekstre edildi. Elde edilen ekstre $50^{\circ} \mathrm{C}^{\prime}$ de indirgenmiş basınç altında etanol buharlaştırılarak 2,66 gr ekstrakt elde edildi.

\subsection{Deney protokolü}

Kafkas Üniversitesi Hayvan Deneyleri Yerel Etik Kurulu'nun 2017-64 revizyonu 2019-058 sayılı onayı ile Kafkas Üniversitesi Deney Hayvanları Uygulama ve Araştırma Merkezi'nden temin edilen 40 adet Wistar albino cinsi diși sıçan her grupta 10 adet olacak şekilde aşağıdaki gibi 4 gruba ayrıldı.

1. Kontrol Grubu-K (n:10): Oral olarak serum fizyolojik,

2. $125 \mathrm{mg} / \mathrm{kg} \mathrm{H}$. reticulatus ekstrakt grubu-HR125 (n:10): Oral olarak $125 \mathrm{mg} / \mathrm{kg} \mathrm{H}$. reticulatus tohum ekstraktı,

3. $250 \mathrm{mg} / \mathrm{kg} \mathrm{H}$. reticulatus ekstrakt grubu-HR250 (n:10): Oral olarak $250 \mathrm{mg} / \mathrm{kg} \mathrm{H}$. reticulatus tohum ekstraktı,

4. $500 \mathrm{mg} / \mathrm{kg} \mathrm{H.} \mathrm{reticulatus} \mathrm{ekstrat} \mathrm{grubu-HR500}$ (n:10): Oral olarak $500 \mathrm{mg} / \mathrm{kg} \mathrm{H}$. reticulatus tohum ekstraktı uygulandı.

Kontrol grubu ile ekstrakt uygulanan gruplar arasında oral uygulamaya bağlı oluşabilecek stresi minimize edebilmek için kontrol grubuna da oral yolla serum fizyolojik uygulandı. Yedi gün sonunda $0,4 \mathrm{ml} / \mathrm{kg}$ sodyum pentobarbital anestezisi altındaki hayvanlardan intrakardiyak olarak antikoagülanlı tüplere kan, servikal dislokasyonu takiben de beyin doku örnekleri alındı. Alınan doku örnekleri serum fizyolojikte yıkandıktan sonra analizlere kadar -20 ${ }^{\circ} \mathrm{C}$ 'de saklandı. Beyin ve plazma numunelerinde ticari ELIZZA kitleri kullanılarak Bcl-2 ve TP53 seviyeleri belirlendi (Elabscience, USA).

\subsection{Antimikrobiyal analizler}

H. reticulatus tohum ekstraktının antimikrobiyal etkilerinin belirlenmesi amaciyla Bacillus subtilis (ATCC 6633) Escherichia coli (ATCC-25922), Klebsiella pneumoniae (ATCC-4352), Pasteurella multocida (ATCC-12945), Pseudomonas aeruginosa (ATCC-27853), Salmonella enteridis (ATCC 13076), Staphylococcus aureus (ATCC-6538), Yersinia enterocolitica (ATCC-27729) bakterileri standart suşları Candida albicans (ATCC 10231) mayası kullanılmıştır.

\subsection{Antimikrobiyal analizler}

Antibakteriyel aktivite tayini için disk difüzyon yöntemi kullanılmıştır [20,21]. Bakteri suşları stok kültürlerden ayrı ayrı $5 \mathrm{ml}$ nutrient brothda süspanse edilerek, 2-5 saat etüvde inkübasyona bırakılmıştır.
$\mathrm{Bu}$ süre sonunda bakteri maya süspansiyonu 0,5 McFarland standardına göre ayarlandıktan sonra içinde Mueller Hinton agarlı ortama 100'er $\mu \mathrm{L}$ ekim yapılmıştır. Steril eküvyon, petri kabına 3 ayrı yönde sürülerek sık aralıklarla tarama şeklinde inoküle edilmiş ve tüm petri plakları bundan sonra 5-20 dakika süre ile oda ısısında kurumaya bırakılmıştır. Süre sonunda agar üzerine $H$. reticulatus tohum ekstraktından $50 \mu \mathrm{L}$ emdirilmiş $5 \mathrm{~mm}$ çapındaki antibiyotik diskleri yerleştirilmiş ve bakteriler $36^{\circ} \mathrm{C}$ 'de 24 saat, maya ise $30^{\circ} \mathrm{C}^{\prime}$ de 48 saat inkübasyona bırakılmıştır. Süre sonunda inhibisyon zon çapları değerlendirilmiştir. Aynı zamanda çözücümüz olan su ve alkol de aynı besiyerine ekim yapılarak inhibisyon olup olmadığına bakılmıştır.

\subsection{Tüp dilüsyon yöntemi}

$H$. reticulatus tohum ekstraktı sıvı besiyerinde iki kat azalan oranlarda $(1,1 / 2,1 / 4,1 / 8,1 / 16)$ sulandırmaları yapılmış ve mikroorganizmaların standart bir inokülumu (1x106 CFU / ml) hazırlanıp her bir tüpe 100 'er $\mu \mathrm{L}$ ekim yapılmıştır. Üremenin kontrolü olarak ekstrakt içermeyen bir tüpe de mikroorganizmalar aynı miktarda inoküle edilmiştir. Besiyerleri $36^{\circ} \mathrm{C}$ 'de 24 saatlik inkübasyon sonunda tüp besiyerleri bulanıklık yönünden incelenmiştir. Gözle görünür bir bulanıklığın olmadığı mikroorganizmaların üremesini önleyen en düşük ekstrakt konsantrasyonu araştırılmıştır [22].

\subsection{Biyokimyasal Analizler İçin Numunelerin Hazırlanması}

Beyin ve plazma numunelerinde ticari ELIZA kitlerindeki prosedüre uygun olarak Bcl-2 ve TP53 seviyeleri belirlendi. Kan numuneleri antikoagülanlı (EDTA'lı) tüplere alındıktan sonra 30 dakika içinde 1000 x g'de $4^{\circ} \mathrm{C}$ de 15 dakika boyunca santrifüj edilerek plazma numuneleri elde edildi. Beyin doku homojenizatları hazırlanırken öncelikle doku üzerinde kalabilen hemolize kan sonuçları etkileyebileceği için soğuk PBS (0.01 M, pH = 7.4) ile durulandı. Beyin dokusu çalışılırken spesifik bir bölge çalışılmamış olup bütün beyin dokuları tartılıp PBS ile 1:9 oranında sulandırılarak homojenize edildi. Homojenizatlar daha sonra süpernatantı elde etmek için 5000 x g'de 5 dakika santrifüj edildi. Daha sonra hem plazma numuneleri hem de süpernatantlarda kit prosedürüne uygun olarak analizler gerçekleştirildi.

\section{7. İstatistiksel analizler}

Antimikrobiyal aktivite denemeleri en az 3 tekrarlı olacak şekilde gerçekleștirilmiştir ve her bir bulgu 2 tekrardan oluşmuştur. Tek-Yönlü Varyans Analizi (One Way ANOVA) ile veriler değerlendirilmiştir. İstatistiksel açıdan $\mathrm{p}<0,05$ olan değerler anlamlı kabul edilir. SPSS programı (standart versiyon 18) ile istatistiksel analizler gerçekleştirilmiştir. 


\section{Bulgular}

H. reticulatus tohum ekstraktının disk difüzyon tekniği ile elde edilen antimikrobiyal test sonuçları Tablo 1'de ve tüp dilüsyon yöntemi ile farklı konsantrasyonlardaki antimikrobiyal etkinliği Tablo 2'de verilmiştir.

Tablo 1. H. reticulatus tohum ekstraktının katı besiyerinde test mikroorganizmaları çevresinde oluşturduğu zon çapları.

\begin{tabular}{lcc} 
çaplarl. & \multicolumn{2}{c}{ Katı besiyerinde İnhibisyon } \\
& \multicolumn{2}{c}{ Zonları (mm) } \\
Test mikroorganizmaları & Ekstrakt & Etanol \\
Escherichia coli & - & - \\
Klebsiella pneumoniae & - & - \\
Pasteurella multocida & - & - \\
Pseudomonas aeruginosa & - & - \\
Staphylococcus aureus & - & - \\
Yersinia enterocolitica & - & - \\
Salmonella enteridis & - & - \\
Bacillus subtilis & - & - \\
Candida albicans & - & - \\
\hline
\end{tabular}

Tablo 2. H. reticulatus tohum ekstraktının tüp dilüsyon yöntemiyle antimikrobiyal etkinliği.

\section{Tüp Dilüsyon Yöntem \\ (Konsantrasyon Oranları - Üreme Durumu)}

$\begin{array}{lllllll}\text { Test mikroorganizmaları } & 1 & 1 / 2 & 1 / 4 & 1 / 8 & 1 / 16 & 1 / 32\end{array}$

Escherichia coli

Klebsiella pneumoniae

Pseudomonas aeruginosa

Staphylococcus aureus

Yersinia enterocolitica

Salmonella enteridis

Bacillus subtilis

Candida albicans

Plazma ve beyin dokularındaki TP53 ve Bcl-2 seviyelerindeki değişimler ise Şekil 1'de gösterilmiştir.
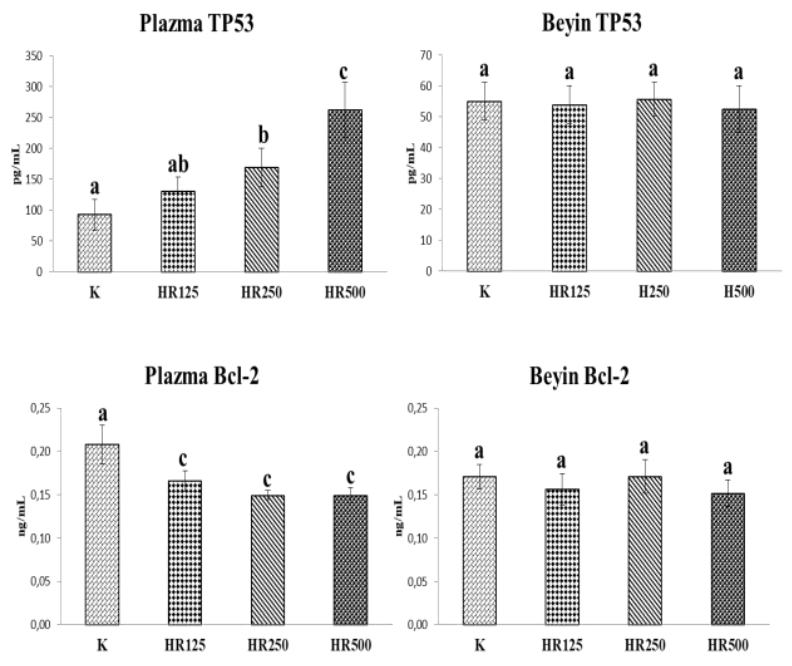

Şekil 1. Farklı dozlarda uygulanan $H$. reticulatus etanol ekstraktının plazma ve beyin TP53 ve Bcl-2 düzeyleri üzerine etkileri, ortalama $\pm S D, n: 10$, a-b, a-c, ab-c $p<0,001$, b-c $p<0,01$
Tablolardaki sonuçlar çalıșmada kullanılan Hyoscyamus reticulatus tohumunun etanol ekstraktının tüp dilüsyon ve disk difüzyon tekniğine göre antimikrobiyal etkisinin bulunmadığını göstermektedir.

Plazma TP53 seviyelerinde HR250 ve HR500 gruplarında $\mathrm{K}$ grubuna göre önemli düzeyde artış olduğu belirlendi (sırasıyla $p<0,01, p<0,001$ ). Hem HR125 hem de HR250 grupları ile HR500 grubu kıyaslandığında ise bu parametre seviyelerinin HR500 grubunda istatistiksel olarak anlaml bir şekilde yükseldiği tespit edildi (sırasıyla $\mathrm{p}<0,001$, $\mathrm{p}<0,01)$. Ayrica HR125 grubunda plazma TP53 seviyelerinin hem K grubuna hem de HR250 grubuna benzer olduğu aralarında istatistiksel önemlilik olmadığı gözlemlendi. Plazma Bcl-2 seviyeleri değerlendirildiğinde ise ekstrakt uygulanan tüm gruplarda K grubuna göre istatistiksel olarak anlamlı azalıșların olduğu tespit edildi $(\mathrm{p}<0,001)$. K ve farklı dozlarda ekstrakt uygulanan grupların beyin dokusu homojenizatlarında TP53 ve Bcl-2 seviyelerindeki değișimler değerlendirildiğinde ise aralarında istatistiksel anlamlılığın olmadığı tespit edildi.

\section{Tartışma ve Sonuç}

Elde edilen sonuçlar, çalışmada kullanılan $H$. reticulatus tohumunun etanol ekstraktının antibakteriyel etkisinin bulunmadığını göstermektedir. Ancak Chalabian ve arkadaşları $H$. reticulatus ve $H$. niger'in çiçek gövde ve köklerinden elde ettikleri alkaloit ekstraktların güçlü antimikrobial etkisi olduğunu rapor etmişlerdir [23]. Bazzaz ve Haririzadeh yaptıkları çalışmada, $H$. reticulatus bitkisinin toprak üstü kısımlarının metanol ekstraktının antibakteriyel aktiviteye sahip olduğunu belirtmiştir [24]. Çalışmalar arasındaki bu değişkenliğin uygulanan ekstraksiyon yöntemlerinin farklı olması, çözücülerin hatta bitkinin yetiştiği ortamdaki toprağın yapısı, ısı, ışık, rakım ve topraktaki azot içeriği gibi dış etkenlerin farklı olmasından veya etil alkolün bu bitki için uygun bir çözücü olmamasından dolayı oluştuğu düşünülmektedir. Yücel ve Yılmaz'da yaptıkları çalışmada; bir bölgedeki farklı arazilerde yetişen Hyoscyamus türlerindeki alkaloit düzeylerinin farklı olabileceğini belirtmişlerdir [25]. Toprağın yapısı, rakım, ıșık, ısı, herbisit uygulamaları ve topraktaki azot içeriği gibi dış etkenlere bağlı olarak alkaloitlerin sentezi değişebilir. Tropan alkaloitlerinin sentezlenmesi ve toprağın pH'sı arasında negatif bir etkileşim olduğu, fosfor, azot, kalsiyum ve potasyum gibi elementlerin varlığında ise bu alkaloitlerin sentezin arttığı bildirilmiştir [26-28].

Yapılan çalışmada beyin dokusunda TP53 ve Bcl-2 seviyelerinde değişim meydana gelmemiş olup ancak plazma seviyelerinde ekstrakt gruplarında doza bağlı olarak PT53 seviyelerinde artış, Bcl-2 seviyelerinde 
ise azalma olduğu tespit edildi. P53'ün iki ana apoptotik yoldan geniş bir sinyal ağını uyardığı bilinmekte olup, ekstrinsik yolakta kaspaz kaskadının aktivasyonunu tetiklediği, intrinsik mitokondriyal yolakta ise Bcl-2 ailesindeki proapoptotik üyelerin (Bax, Apaf-1, Fas) üretimini arttırdığı, antiapoptotik üyelerin üretimini (Bcl-2, Bcl-xL) ise baskılayarak ve apoptozun oluşumunu desteklediği ileri sürülmektedir [18, 29]. Yapılan çalışmada $H$. reticulatus tohum ekstraktının beyin dokusunu etkilememesinin sebepleri arasinda verilen ekstraktın dozlarının ve uygulama sürenin etkili olabileceğini, plazma seviyelerinde meydana gelen bu değişimler değerlendirildiğinde ise diğer organ ve/veya organlarda apoptozisi uyardığını düşünmekteyiz.

Sonuç olarak yapılan çalışmada $H$. reticulatus tohumunun etanol ekstraktının antimikrobiyal etkinliğinin olmadığı çalışmanın in vivo basamağında ise farklı dozlarda uygulanan bitki ekstraktının beyin dokusunda olmasa da diğer organ ve/veya organlarda apoptozisi uyarabileceği plazma numunelerindeki değişimlerle belirlenmiştir. Ancak daha sonraki çalıșmalarda bitki ekstraktının farklı organ ve/veya organlar üzerinde etkinliğinin daha detaylı araştırılması gerektiğini düşünmekteyiz.

\section{Teşekkür}

$\mathrm{Bu}$ çalışmayı maddi olarak destekleyen Kafkas Üniversitesi Bilimsel Araştırmalar Koordinatörlüğüne teşekkür ederiz (2018-TS-07).

\section{Kaynakça}

[1] Baytop, T. 1999. Türkiye'de Bitkilerle Tedavi. 2.baskı. Nobel Tıp Kitabevleri, İstanbul, 480s.

[2] Madani, H., Hosseini, B., Dehghan, E., Rezaeichiyaneh, E. 2015. Enhanced production of scopolamine in induced autotetraploid plants of Hyoscyamus reticulatus L. Acta Physiologiae Plantarum, 37(3), 55.

[3] Ghorbanpour, M., Hatami, M., Hatami, M. 2015. Activating antioxidant enzymes, hyoscyamine and scopolamine biosynthesis of Hyoscyamus niger L. plants with nano-sized titanium dioxide and bulk application. Acta Agriculturae Slovenica, 105, 23-32.

[4] Evans, W. C., Ramsey, K. P. A. 1983. Alkaloids of the Solanaceae tribe Anthocercideae. Phytochemistry, 22(10), 22192225.

[5] Bahmanzadegan, A., Sefidkon, F., Sonboli, A. 2010. Determination of hyoscyamine and scopolamine in four Hyoscyamus species from Iran. Iranian Journal of Pharmaceutical Research, 65-70.
[6] Karadaş, S., Güler, A., Şahin, M., Behçet, L. 2012. 32 haftalık gebede banotu zehirlenmesi. Van Tıp Dergisi, 19(1), 36-38.

[7] Kürkçüoğlu, M. 1970. Henbane (Hyoscyamus niger) poisoning in the vicinity of Erzurum. The Turkish Journal of Pediatrics, 12(1), 48-56.

[8] Güler, G. Ö. 2012. Studies on antioxidant properties of the different solvent extracts and fatty acid composition of Hyoscyamus reticulatus L. Journal Food Biochemistry, 36(5), 532-538.

[9] Singh, S. K., Pandey, V. D., Evaluation of Hyoscyamus niger L. extracts for antibacterial activity. Plant Archives, 9(1), 97-100.

[10] Dulger, B., Goncu, B. S., Gucin, F. 2010. Antibacterial activity of the seeds of Hyoscyamus niger L. (Henbane). Asian Journal of Chemistry, 22(9), 6879-6883.

[11] Erkal, H., Özyurt, Y., Arıkan, Z. 2006. Yaşlı hastada henbane (Hyoscyamus niger) sonrası antikolinerjik sendrom. Turkish Journal of Geriatrics, 9(3), 188-191.

[12] Straus, A. 1989. Hyoscyamus spp: In vitro culture and production of tropane alkaloids. ss 286-314. In Medicinal and Aromatic Plants II, Springer, Berlin Heidelberg New York, 538s.

[13] Yılmaz, 0. 1990. Bursa yöresinde yetişen önemli zehirli bitkilerin toksikolojik özellikleri. Uludağ Üniversitesi, Sağlık Bilimleri Enstitüsü, Doktora Tezi, 93s, Bursa.

[14] Kartal, M., Kurucu, S., Altun, L., Ceyhan, T., Sayar, E., Cevheroğlu, S., Yetkin, Y. 2003. Quantitative analysis of l-hyoscyamine in Hyoscyamus reticulatus L. By GC-MS. Turkish Journal of Chemistry, 27(5), 565-569.

[15] Gross, A., McDonnell, J. M., Korsmeyer, S. J. 1999. BCL-2 family members and the mitochondria in apoptosis. Genes \& Development, 13(15), 18991911.

[16] Certo, M., Moore, V. D. G., Nishino, M., Wei, G., Korsmeyer S., Armstrong S. A., Letai A. 2006. Mitochondria primed by death signals determine cellular addiction to antiapoptotic BCL-2 family members. Cancer Cell, 9(5), 351365.

[17] Martinou, J. C., Youle, R. J. 2011. Mitochondria in apoptosis: Bcl-2 family members and mitochondrial dynamics. Developmental Cell, 21(1), 92-101.

[18] Coşkun, G., Özgür, H. 2014. Apoptoz ve nekrozun moleküler mekanizması. Arşiv Kaynak Tarama Dergisi, 20(3), 145-158.

[19] Fridman, J. S., Lowe, S. W. 2003. Control of apoptosis by p53. Oncogene, 22(56), 9030-9040. 
[20] Murray, P. R., Baron, E., Pfaller, M., Tenover, F. C., Yolke, R. H. 1995. Manual Clinical Microbiology. ASM, Washington DC, 1356s.

[21] Sacchetti, G., Maietti, S., Muzzoli, M,, Scaglianti, M., Manfredini, S., Radice, M., Bruni, R. 2005. Comparative evaluation of 11 essential oils of different origin as functional antioxidants, antiradicals and antimicrobials in foods. Food Chemistry, 91(4), 621-632.

[22] Kumar, A., Gupta, R. S. 1984. A note on the sensitivity of enterotoxigenic Staphylococcus aureus for garlic extract (Allium sativum Linn). Indian Veterinary Journal, 61(1), 718-719.

[23] Chalabian, F., Majd, A., Mehrabian, S., Falahian, F. 2002. A study of growth inhibitory effect of alkaloids of two species of genus hyoscyamus on some kinds of microbes of skin. Journal of Sciences, 12(43), 3371-3378.

[24] Bazzaz, B., Haririzadeh, G. 2003. Screening of Iranian plants for antimicrobial activity. Pharmaceutical Biology, 41(8), 573-583.
[25] Yücel Mercan, U., Yılmaz, O. 2014. Van Yöresinde Yetişen İki Hyoscyamus (Banotu) Türünün Total Alkaloid Miktarları. Van Veterinary Journal, 25(3), 77-80.

[26] Chatterjee, S. K., Nandi, R. P., Baharati, P., Yonjan, M. K. 1988. Improvement studies on some alkaloid yielding medicinal plants. Medicinal and Aromatic Spice Plants, 180(1), 39-46.

[27] Poutaraud, A., Girardin, P. 2005. Influence of chemical characteristics of soil on mineral and alkaloid seed contents of Colchicum autumnale L. Environmental and Experimental Botany, 54(2), 101-108.

[28] Nejadhabibvash, F., Rahmani, F., Heidari, R., Jamei, R., Azimi, F. 2012. Study of inheritance and environment on tropane alkaloids within Hyoscyamus species. Australian Journal of Crop Science, 6(10), 1428-1434.

[29] Haupt, S., Berger, M., Goldberg, Z., Haupt, Y. 2003. Apoptosis-the p53 network. Journal of Cell Science, 116(20), 4077-4085. 